\title{
Barriers to Antenatal Care Utilization in Indonesia
}

\author{
Ratna Dwi Wulandari $^{1}$, Agung Dwi Laksono², Tety Rachmawati², Rukmini Rukmini² \\ ${ }^{1}$ Faculty of Public Health, Universitas Airlangga, Surabaya, Indonesia. Campus C Mulyorejo Surabaya, Indonesia, \\ ${ }^{2}$ Researcher, National Institute of Health Research and Development, Indonesian Ministry of Health, Jakarta, \\ Indonesia
}

\begin{abstract}
MMR data in Indonesia fluctuates according to the data source used. Based on Indonesia Demographic and Health Survey data, MMR in Indonesia in 1990 was 390 per 100,000 live births, in 2004/2007 it was $228 / 100,000$ live births, then increased sharply in $2008-2012$ by $359 / 100,000$ live births. Whereas based on the 2015 SUPA data, MMR in Indonesia decreased by 305 per 100,000 per live birth. This study aims to analyze the barrier to $\geq 4$ ANC visits during pregnancy. The analysis uses the 2017 Indonesian Demographic and Health Survey data. Stratification and multistage random sampling method get 15,351 respondents. Barrier determination was done using Binary Logistic Regression. The barriers consisted of the following variables: young age, low education, high parity, poverty, not having health insurance, not being able to read, not being exposed to the media, never using the internet, not knowing the danger signs of pregnancy, and belief in traditional birth attendants.
\end{abstract}

Keywords: Antenatal care, healthcare utilization, the barrier of utilization, mother and child health.

\section{Introduction}

Maternal Mortality Rate (MMR) is an indicator of the level of women's health that illustrates the level of access, integrity, and effectiveness of the health sector. Therefore, MMR is often used as an indicator of the welfare level of a country. Since 1988, the Indonesian Ministry of Health has focused its policy on improving maternal health and well-being, as MMR's reaction is still high in Indonesia. Starting from the "Safe Motherhood" program in 1988, the Dear Mother Movement in 1996, the National Strategic Plan for Making Pregnancy Safer in 2001-2010, Birth Assurance in 2011, to the National Action Plan for Acceleration in Decreasing Maternal Mortality Rates 2013-2015 ${ }^{1}$.

MMR data in Indonesia fluctuates according to the data source used. Based on Indonesia Demographic

\section{Corresponding Author:}

\section{Ratna Dwi Wulandari}

Faculty of Public Health, Universitas Airlangga, Surabaya, Indonesia. Campus C Mulyorejo Surabaya, Indonesia

e-mail: ratna-d-w@fkm.unair.ac.id and Health Survey Data, MMR in Indonesia in 1990 was 390 per 100,000 live births, in $2004 / 2007$ it was $228 / 100,000$ live births, then increased sharply in 20082012 by $359 / 100,000$ live births. Whereas based on the 2015 SUPA data, MMR in Indonesia decreased by 305 per 100,000 per live birth ${ }^{1}$.

One of the policies to reduce MMR in Indonesia is an effort to improve the quality of health services, especially pregnant woman examination services by professionals who are following integrated Antenatal Care (ANC) service standards. Minimum ANC standard services include 1) Measure Weigh; 2) Measure the circumference of the upper arm; 3) Measure blood pressure; 4) Measure fundal height; 5) Calculate fetal heart rate; 6) Determine the fetal presentation; 7) Give TT immunization; 8) Give blood plus tablets (Fe); 9) Check routine and specialized laboratories (blood type examination, blood hemoglobin level check, urine protein check, blood sugar level check, malaria blood test, syphilis test, HIV test, and smear examination); 10) Management or handling of cases ${ }^{2}$.

Several recent studies have shown that healthseeking behavior is influenced by individual and household factors, including education, marital status, 
wealth status, health insurance ${ }^{3}$, and health belief ${ }^{4}$. Besides, external factors such as the availability of information and media exposure also contribute to health-seeking behavior ${ }^{5}$.

This study was conducted to analyze the barrier of the use of $\geq 4$ ANC visits during pregnancy in women aged 15-49 years old who gave birth in the last five years in Indonesia. The results of this study are useful for the Ministry of Health to determine the acceleration of ANC utilization policy of at least 4 visits during pregnancy to reduce maternal mortality in Indonesia.

\section{Materials and Method}

This research was conducted using secondary data from the 2017 Indonesian Demographic Data Survey (IDHS). The IDHS was part of the International Demographic and Health Survey program conducted by the Inner City Fund. The 2017 IDHS sampling method was done by stratification and multistage random sampling. With the analysis unit of women aged 1549 years old who had given birth in the last 5 years, a sample size of 15,351 women was obtained.
Following recommendations from the Ministry of Health, ANC was performed at least 4 times during pregnancy, which was at least 1 time in the first trimester, at least 1 time in the second trimester, and at least 2 times in the third trimester ${ }^{6}$.Other variables analyzed are the place of residence, age, marital status, education level, parity, wealth status, health insurance, literacy, media exposure, frequency of media, use of the internet, know the danger of pregnancy, and belief in traditional birth attendants. Barrier determination was done using Binary Logistic Regression because of the nature of the dependent variable. All statistical analyses were carried out using SPSS 21 software.

\section{Results and Discussion}

Table 1 is a statistical description of the sociodemographic characteristics of respondents. There are significant differences between women who make $<4$ ANC visits compared to women who make $\geq 4$ ANC visits in all socio-demographic categories. Women who make $\geq 4$ ANC visits are more dominant in urban areas and the 30-34 age group.

Table 1. Socio-Demographic of Respondents $(n=15,351)$

\begin{tabular}{|c|c|c|c|c|}
\hline \multirow{2}{*}{ Variables } & \multicolumn{2}{|c|}{ ANC } & \multirow{2}{*}{ All } & \multirow{2}{*}{$\mathbf{P}$} \\
\hline & $<4$ visits & $\geq 4$ visits & & \\
\hline \multicolumn{4}{|l|}{ Place } & $0.000 * * *$ \\
\hline - Urban & $627(34.45 \%)$ & $6941(51.30 \%)$ & $7568(49.30 \%)$ & \\
\hline - Rural(ref.) & $1193(65.55 \%)$ & $6590(48.70 \%)$ & $7783(50.70 \%)$ & \\
\hline \multicolumn{4}{|l|}{ Age } & $<0.001 * * *$ \\
\hline - $15-19$ & $102(5.60 \%)$ & $314(2.32 \%)$ & $416(2.71 \%)$ & \\
\hline - $20-24$ & $309(16.98 \%)$ & $2105(15.56 \%)$ & $2414(15.73 \%)$ & \\
\hline - 25-29 & $394(21.65 \%)$ & $3453(25.51 \%)$ & $3847(25.06 \%)$ & \\
\hline - $30-34$ & $408(22.42 \%)$ & $3555(26.27 \%)$ & $3963(25.82 \%)$ & \\
\hline - $35-39$ & $351(19.29 \%)$ & $2705(19.99 \%)$ & $3056(19.91 \%)$ & \\
\hline - $40-44$ & $201(11.04 \%)$ & $1156(8.54 \%)$ & $1357(8.84 \%)$ & \\
\hline - 45-49 (ref.) & $55(3.02 \%)$ & $243(1.80 \%)$ & $298(1.94 \%)$ & \\
\hline \multicolumn{4}{|l|}{ Marital } & $<0.001 * * *$ \\
\hline - Single/Never in union (ref.) & $8(0.44 \%)$ & $20(0.15 \%)$ & $28(0.18 \%)$ & \\
\hline - Married/Living with partner & $1702(93.52 \%)$ & $13141(97.12 \%)$ & $14843(96.69 \%)$ & \\
\hline - Widowed/Divorced & $110(6.04 \%)$ & $370(2.73 \%)$ & $480(3.13 \%)$ & \\
\hline \multicolumn{4}{|l|}{ Education } & $<0.001 * * *$ \\
\hline - No education(ref.) & $88(4.84 \%)$ & $116(0.86 \%)$ & $204(1.33 \%)$ & \\
\hline - Primary & $695(38.19 \%)$ & $3164(23.38 \%)$ & $3859(25.14 \%)$ & \\
\hline
\end{tabular}




\begin{tabular}{|c|c|c|c|c|}
\hline \multirow{2}{*}{ Variables } & \multicolumn{2}{|c|}{ ANC } & \multirow{2}{*}{ All } & \multirow{2}{*}{$\mathbf{P}$} \\
\hline & $<4$ visits & $\geq 4$ visits & & \\
\hline - Secondary & $857(47.09 \%)$ & $7771(57.43 \%)$ & $8628(56.20 \%)$ & \\
\hline - Higher & $180(9.89 \%)$ & $2480(18.33 \%)$ & $2660(17.33 \%)$ & \\
\hline \multicolumn{4}{|l|}{ Parity } & $<0.001 * * *$ \\
\hline$\cdot<2$ & $459(25.22 \%)$ & $4296(31.75 \%)$ & $4755(30.98 \%)$ & \\
\hline - $2-4$ & $1013(55.66 \%)$ & $8394(62.04 \%)$ & $9407(61.28 \%)$ & \\
\hline - $>4$ (ref.) & $348(19.12 \%)$ & $841(6.22 \%)$ & $1189(7.75 \%)$ & \\
\hline \multicolumn{4}{|l|}{ Wealth status } & $<0.001 * * *$ \\
\hline - Poorest (ref.) & $913(50.16 \%)$ & $3160(23.35 \%)$ & $4073(26.53 \%)$ & \\
\hline - Poorer & $368(20.22 \%)$ & $2663(19.68 \%)$ & $3031(19.74 \%)$ & \\
\hline - Midle & $260(14.29 \%)$ & $2630(19.44 \%)$ & $2890(18.83 \%)$ & \\
\hline - Richer & $171(9.40 \%)$ & $2589(19.13 \%)$ & $2760(17.98 \%)$ & \\
\hline - Richest & $108(5.93 \%)$ & $2489(18.39 \%)$ & $2597916.92 \%)$ & \\
\hline \multicolumn{4}{|l|}{ Health insurance } & $<0.001 * * *$ \\
\hline - No(ref.) & $851(46.76 \%)$ & $4988(36.86 \%)$ & $5839(38.04 \%)$ & \\
\hline - Yes & $969(53.24 \%)$ & $8543(63.14 \%)$ & $9512(61.96 \%)$ & \\
\hline
\end{tabular}

Note: ${ }^{*} \mathrm{p}<0.05 ;{ }^{* *} \mathrm{p}<0.01 ;{ }^{* * *} \mathrm{p}<0.001$.

Table 1 informs that women who make ANC visits during pregnancy are dominated by women who are married or living with partners. The education level category is dominated by secondary education women. Table 1 shows that women who made ANC visits during pregnancy were dominated by women who had parity 2-4 and were very poor. Dominance is also shown by women who are covered by health insurance.

Table 2 is a statistical description of the characteristics of knowledge and information exposure of respondents aged 15-49 years old who gave birth in the last five years in Indonesia. Table 2 informs that there are significant differences between women who make $<4$ ANC visits compared with women who make $\geq 4$ ANC visits during pregnancy in all categories.
Table 2 shows that women who were able to read whole sentences were exposed to the media less than once a week, and had never used the internet were more dominant in both ANC frequency categories. While in the "know the danger sign of pregnancy" category, the group of women who made $\geq 4$ ANC visits during pregnancy was dominated by those who knew. While the group of women who made $\geq 4$ ANC visits during pregnancy was dominated by those who did not know. Table 2 informs us that in both categories ANC frequencies were dominated by women who did not believe in traditional birth attendants.

Table 2. Knowledge and exposure of information $(n=15,351)$

\begin{tabular}{|c|c|c|c|c|}
\hline \multirow{2}{*}{ Variables } & \multicolumn{2}{|c|}{ ANC } & \multirow{2}{*}{ All } & \multirow{2}{*}{$\mathbf{P}$} \\
\hline & $<4$ visits & $\geq 4$ visits & & \\
\hline \multicolumn{4}{|l|}{ Literacy } & $<0.001 * * *$ \\
\hline - Cannot read at all (ref.) & $180(9.89 \%)$ & $324(2.39 \%)$ & $504(3.28 \%)$ & \\
\hline - Able to read only part of sentences & $96(5.27 \%)$ & $251(1.85 \%)$ & $347(2.26 \%)$ & \\
\hline - Able to read whole sentence & $1540(84.62 \%)$ & $12939(95.62 \%)$ & $14479(94.32 \%)$ & \\
\hline - Blind/visually impaired & $4(0.22 \%)$ & $17(0.13 \%)$ & $21(0.14 \%)$ & \\
\hline
\end{tabular}




\begin{tabular}{|c|c|c|c|c|}
\hline \multirow{2}{*}{ Variables } & \multicolumn{2}{|c|}{ ANC } & \multirow{2}{*}{ All } & \multirow{2}{*}{$\mathbf{P}$} \\
\hline & $<4$ visits & $\geq 4$ visits & & \\
\hline \multicolumn{4}{|l|}{ Media exposure } & $<0.001 * * *$ \\
\hline - No (ref.) & $185(10.16 \%)$ & $414(3.06 \%)$ & $599(3.90 \%)$ & \\
\hline - Yes & $1635(89.84 \%)$ & $13117(96.94 \%)$ & $14752(96.10 \%)$ & \\
\hline \multicolumn{4}{|l|}{ Frequency of media } & $<0.001 * * *$ \\
\hline - Less than once a week (ref.) & $1394(76.59 \%)$ & $9109(67.32 \%)$ & $10503(68.42 \%)$ & \\
\hline - At least one a week & $426(23.41 \%)$ & $4422(32.68 \%)$ & $4848(31.58 \%)$ & \\
\hline \multicolumn{4}{|l|}{ Use of internet } & $<0.001 * * *$ \\
\hline - Never (ref.) & $1349(74.12 \%)$ & $7029(51.95 \% 0$ & $8378(54.58 \%)$ & \\
\hline - Yes, last 12 months & $428(23.52 \%)$ & $6221(45.98 \%)$ & $6649(43.31 \%)$ & \\
\hline - Yes, before last 12 month & $43(2.36 \%)$ & $281(2.08 \%)$ & $324(2.11 \%)$ & \\
\hline \multicolumn{4}{|c|}{ Know the danger sign of pregnancy } & $<0.001 * * *$ \\
\hline - No (ref.) & $1061(58.30 \%)$ & $4406(32.56 \%)$ & $5467(35.61 \%)$ & \\
\hline - Yes & $759(41.70 \%)$ & $9125(67.44 \%)$ & $9884(64.39 \%)$ & \\
\hline \multicolumn{4}{|c|}{ Belief in traditional birth attendant } & $<0.001 * * *$ \\
\hline - No (ref.) & $1661(91.26 \%)$ & $13034(96.33 \%)$ & $14695(95.73 \%)$ & \\
\hline - Yes & $159(8.74 \%)$ & $497(3.67 \%)$ & $656(4.27 \%)$ & \\
\hline
\end{tabular}

Note: ${ }^{*} \mathrm{p}<0.05 ;{ }^{* *} \mathrm{p}<0.01 ;{ }^{* * *} \mathrm{p}<0.001$.

Table 3 shows the results of the binary logistic regression test which illustrates the barrier of using $\mathrm{ANC}$ in Indonesia. As reference is $<4$ ANC visits during pregnancy. Table 3 shows that women in the 15-19 age group were 0.286 times more likely than women in the 44-49 age group to make $\geq 4$ ANC visits during pregnancy. While women in the 20-24 age group were
0.569 times more likely than women in the 44-49 age group. This shows that younger age is a barrier to make $\geq 4$ ANC visits during pregnancy. A study in Angola from a different perspective also found similar results. The study found that older women had better chances of utilizing $\mathrm{ANC}^{7}$.

Table 3. Binary Logistic Regression of ANC Utilization $(n=15,351)$

\begin{tabular}{|l|c|c|c|c|}
\hline \multirow{2}{*}{ Predictor } & \multicolumn{4}{|c|}{$\geq$ 4 ANC visits } \\
\cline { 2 - 5 } & P & OR & Lower Bound & Upper Bound \\
\hline Place: Urban & 0.905 & 0.993 & 0.879 & 1.121 \\
\hline Age: $15-19$ & $<0.001^{* * *}$ & 0.286 & 0.185 & 0.443 \\
\hline Age: $20-24$ & $0.003^{* *}$ & 0.569 & 0.392 & 0.827 \\
\hline Age: $25-29$ & 0.195 & 0.790 & 0.554 & 1.128 \\
\hline Age: $30-34$ & 0.668 & 0.927 & 0.655 & 1.312 \\
\hline Age: $35-39$ & 0.849 & 1.034 & 0.734 & 1.458 \\
\hline Age: $40-44$ & 0.799 & 0.955 & 0.668 & 1.364 \\
\hline Marital: Married/Living with partner & 0.487 & 1.360 & 0.571 & 3.238 \\
\hline Marital: Widowed/Divorced & 0.326 & 0.639 & 0.261 & 1.562 \\
\hline Education: Primary & $0.013^{*}$ & 1.593 & 1.104 & 2.300 \\
\hline
\end{tabular}




\begin{tabular}{|c|c|c|c|c|}
\hline \multirow{2}{*}{ Predictor } & \multicolumn{4}{|c|}{$\geq 4$ ANC visits } \\
\hline & $\mathbf{P}$ & OR & Lower Bound & Upper Bound \\
\hline Education: Secondary & $0.007 * *$ & 1.713 & 1.161 & 2.526 \\
\hline Education: Higher & 0.507 & 1.155 & 0.755 & 1.767 \\
\hline Parity: $<2$ & $<0.001 * * *$ & 3.930 & 3.142 & 4.915 \\
\hline Parity: $2-4$ & $<0.001 * * *$ & 2.627 & 2.215 & 3.115 \\
\hline Wealth status: Poorer & $<0.001 * * *$ & 1.528 & 1.323 & 1.764 \\
\hline Wealth status: Midle & $<0.001 * * *$ & 1.807 & 1.530 & 2.134 \\
\hline Wealth status: Richer & $<0.001 * * *$ & 2.328 & 1.907 & 2.842 \\
\hline Wealth status: Richest & $<0.001 * * *$ & 3.127 & 2.441 & 4.006 \\
\hline Insurance: Yes & $<0.001 * * *$ & 1.408 & 1.266 & 1.566 \\
\hline Literacy: Able to read only part of sentences & 0.554 & 0.902 & 0.640 & 1.270 \\
\hline Literacy: Able to read whole sentence & $0.016^{*}$ & 1.385 & 1.061 & 1.807 \\
\hline Literacy: Blind/visually impaired & 0.680 & 1.273 & 0.404 & 4.010 \\
\hline Media exposure: yes & $0.004 * *$ & 1.366 & 1.106 & 1.687 \\
\hline Frequency of media: At least one a week & 0.196 & 0.920 & 0.810 & 1.044 \\
\hline Internet: Yes. last 12 months & $<0.001 * * *$ & 1.413 & 1.215 & 1.644 \\
\hline Internet: Yes. before last 12 month & 0.647 & 1.085 & 0.766 & 1.537 \\
\hline Know the danger sign of pregnancy: Yes & $<0.001 * * *$ & 1.900 & 1.703 & 2.121 \\
\hline Belief in traditional birth attendant: Yes & $<0.001 * * *$ & 0.527 & 0.432 & 0.643 \\
\hline
\end{tabular}

Note: ${ }^{*} \mathrm{p}<0.05 ;{ }^{* *} \mathrm{p}<0.01 ;{ }^{* * *} \mathrm{p}<0.001$.

The women with primary education are 1.593 times more likely than no education women to make $\geq 4$ ANC visits during pregnancy. While women with secondary education were 1.713 times more likely than no education. This condition shows that uneducated is a barrier to $\geq 4$ ANC visits during pregnancy. The result is similar to previous research that found the same phenomenon ${ }^{8}$. The higher a person's education, the better her chance in utilizing health services, because she knows about her needs, and knows how to fulfill them ${ }^{9-11}$.

The research shows that have many children is a barrier to making $\geq 4$ ANC visits. The results of this analysis are in line with studies conducted in Eastern Ethiopia. The study found that primiparous and multiparous women had lower birth preparedness and complication readiness than primiparous women. Having many children was also informed as a predictor of neonatal death in Indonesia ${ }^{12,13}$

Wealth status in all categories there is a better chance than the poorest women. The richer the more likely it is to make $\geq 4$ ANC visits. This condition shows that poverty is a barrier to $\geq 4 \mathrm{ANC}$ visits during pregnancy. Moreover, the women who were covered by health insurance had 1.408 times more likely than women who were not covered by health. This shows that not having health insurance is a barrier to making $\geq 4$ ANC visits during pregnancy.

Poor and without health insurance were found as barriers to get $\geq 4$ ANC visits. These two conditions are interrelated. In general, it is known that health insurance can increase public access to health care facilities ${ }^{14}$. The same condition also applies to accessibility to get $\geq 4$ ANC visits. Not having health insurance is a barrier to getting $\geq 4$ ANC visits during pregnancy. Health financing policies in Indonesia try to reduce this barrier by providing subsidies for contributions to the National Health Insurance mechanism. It is hoped that this policy can improve the access of the poor to health services, including the $\mathrm{ANC}^{15}$.

Table 3 informs us that in the literacy category, women who were able to read whole sentences were 1.385 times more likely than women who could not read 
at all to make $\geq 4 \mathrm{ANC}$ visits. This condition shows that the inability in literacy is a barrier to make $\geq 4$ ANC visits during pregnancy. This finding is in line with the results of research in Afghanistan which found that women who could read were three times better than those who could not read when using $\mathrm{ANC}^{16}$. Literacy ability is a determining factor in the level of knowledge of obstetric danger signs and perceptions of the need for obstetric care $^{17}$.

Table 3 shows that women who were exposed to the media were 1.366 times more likely than women who were not exposed to the media to make $\geq 4$ ANC visits. This shows that media exposure is a barrier to making $\geq 4$ ANC visits during pregnancy. While the frequency of media exposure did not show any influence on the ANC frequency. Moreover, the women who used the internet last 12 months were 1.413 times more likely than women who never used the internet. This shows that never using the internet is a barrier to making $\geq 4$ ANC visits during pregnancy. This condition is in line with the inability to read and low education, as well as its effects, being ignorant of the danger signs of pregnancy.

Table 3 shows that women who knew the danger sign of pregnancy were 1.900 times more likely than women who did not know the danger sign of pregnancy. This shows that ignorance of the danger sign of prevention is a barrier to making $\geq 4$ ANC visits. While the women who believe in traditional birth attendants are 0.527 times more likely than women who do not believe in traditional birth attendants. This shows that belief in traditional birth attendants is a barrier to make $\geq 4$ ANC visits during pregnancy. Indonesia has thousands of ethnic groups. There are still many health beliefs that exist among these tribes. This condition encourages Indonesian women to still trust traditional birth attendants ${ }^{4}$.

\section{Conclusions}

Based on the results of the study, it could be concluded that 10 variables become a barrier for Indonesian women to make $\geq 4$ ANC visits during pregnancy. The barriers consisted of the following variables: young age, low education, high parity, poverty, not having health insurance, not being able to read, not being exposed to the media, never using the internet, not knowing the danger signs of pregnancy, and belief in traditional birth attendants.

Acknowledgments: The author would like to thank the ICF International, who has agreed to allow the 2017 IDHS data to be analyzed in this article.

\section{Source of Funding: Self-funding}

Conflict of Interest: The authors declare no conflict of interest, financial or otherwise.

Ethical Clearance: The 2017 IDHS has received ethical clearance from the National Ethics Commission. Utilization of the 2017 IDHS data in this study has been permitted by ICF International through its website: https://dhsprogram.com/data/new-user-registration.cfm.

\section{References}

1. Communication and Community Service Bureau Ministry of Health Republic of Indonesia. The Ministry of Health Encourages Development in the 4.0 Era (Kemenkes Dorong Pembangunan SDM Era 4.0.) [Internet]. Jakarta; 2019. Available from: http:// www.depkes.go.id/article/print/19031200002/ kemenkes-dorong-pembangunan-sdm-era-4-0.html

2. Directorate General of Community Health Development. Guidelines for Integrated Antenatal Services (Pedoman Pelayanan Antenatal Terpadu). Jakarta: Ministry of Health of the Republic of Indonesia; 2010.

3. Wulandari RD, Laksono AD. Relationship between Midwife Ratio and Performance of Maternal and Child Health Programs in Indonesia (Hubungan antara Rasio Bidan dengan Kinerja Program Kesehatan Ibu dan Anak di Indonesia). Bul Penelit Sist Kesehat. 2019;22(3):208-214.

4. Laksono AD, Soerachman R, Angkasawati TJ. Case Study of Muyu Ethnic's Maternal Health in Mindiptara District-Boven Digoel (Studi Kasus Kesehatan Maternal Suku Muyu di Distrik Mindiptana, Kabupaten Boven Digoel). J Reprod Heal. 2016;07/03:145-55.

5. Bago J-L, Lompo ML. Exploring the linkage between exposure to mass media and HIV awareness among adolescents in Uganda. Sex Reprod Healthc. 2019;21:1-8.

6. National Population and Family Planning Board, Statistics Indonesia, Ministry of Health, The DHS Program. Indonesia Demographic and Health Survey 2017 [Internet]. Jakarta; 2018. Available from: https://www.dhsprogram.com/pubs/pdf/ FR342/FR342.pdf 
7. Rosário EVN, Gomes MC, Brito M, Costa D. Determinants of maternal health care and birth outcome in the Dande Health and Demographic Surveillance System area, Angola. PLoS One. 2019;14(8):Article number e0221280.

8. Tayfur I, Günaydin M, Suner S. Healthcare Service Access and Utilization among Syrian Refugees in Turkey. Ann Glob Heal. 2019;85(1).

9. Wulandari $\mathrm{RD}$, Laksono $\mathrm{AD}$. Education as predictor of the knowledge of pregnancy danger signs in Rural Indonesia. Int J Innov Creat Chang. 2020;13(1):1037-51.

10. Rohmah N, Yusuf A, Hargono R, Laksono AD, Masruroh, Ibrahim I, et al. Determinants of teenage pregnancy in Indonesia. Indian $\mathrm{J}$ Forensic Med Toxicol. 2020;14(3):2080-5.

11. Laksono AD, Wulandari RD. Predictors of Hospital Utilization Among Papuans in Indonesia. Indian J Forensic Med Toxicol. 2020;14(2):2319-24.

12. Wulandari $\mathrm{RD}$, Laksono $\mathrm{AD}$. Is parity a predictor of neonatal death in Indonesia? Analysis of the 2017 Indonesia demographic and health survey. Indian J Forensic Med Toxicol. 2020;14(3):2161-6.
13. Laksono AD, Wulandari RD. Understanding Neonatal Death in Urban Area in Indonesia. Medico-Legal Updat. 2020;20(2):805-9.

14. Laksono ADAD, Soedirham O, Saptandari P, Wulandari RDRD. Study of family size among tenggerese in Indonesia. Int J Innov Creat Chang. 2020;13(4):964-78.

15. Agustina R, Dartanto T, Sitompul R, Susiloretni KA, Suparmi, Achadi EL, et al. Universal health coverage in Indonesia: concept, progress, and challenges. Lancet. 2019;393(10166):75-102.

16. Azimi MW, Yamamoto E, Saw YM, Kariya T, Arab AS, Sadaat SI, et al. Factors associated with antenatal care visits in Afghanistan: secondary analysis of Afghanistan Demographic and Health Survey 2015. Nagoya J Med Sci. 2019;81(1):12131.

17. Oguntunde O, Nyenwa J, Yusuf FM, Dauda DS, Salihu A, Sinai I. Factors associated with knowledge of obstetric danger signs and perceptions of the need for obstetric care among married men in northern Nigeria: A cross-sectional survey. BMC Pregnancy Childbirth. 2019;19(1):Article number 123. 